\title{
Learning as moments of friction and opportunity: An autoethnography of ECR identities in queer time
}

\author{
Ruth Weatherall \\ $\underline{\text { Ruth.Weatherall@uts.edu.au }}$ \\ Sumati Ahuja \\ Sumati.Ahuja@uts.edu.au
}

Management Learning (Forthcoming) Special Issue: Identity and Learning (Not) to be Different 


\begin{abstract}
In this article, we explore how time and temporality shape the identities of early career researchers as they learn to become academics. We engage in a collaborative autoethnography to reflect on how our shared identities as middle-class women and our divergences in age, ethnicity, familial status, and sexuality shaped our embodied experiences of becoming academics. Drawing on the concept of queer time, we reconceptualise the becoming of newcomers as they learn (or do not learn) to belong to academia. We illustrate how queer time interrupts normative ideas of newcomer learning as progress, development, and reproduction. We suggest that learning may alternatively be understood as 'moments of friction' and 'moments of opportunity' in which newcomers to the academy feel out of step, out of place, and out of time. We conceptualise these moments as simultaneously painful yet productive of possibilities for learning to become an academic, differently.
\end{abstract}

Key words: becoming, queer theory, ECAs, early-career researchers, identity, newcomers.

\title{
Introduction
}

The most important question in my end of year performance review was clear: what did you publish this year? The solitary question may not come as a surprise to those embroiled in contemporary academia in which the mantra 'publish or perish' lurks resolutely behind the dais of research excellence (Lund, 2012), but it was still a shock to me. If felt as though I had missed a step in the dark. My body searching for a firm surface that wasn't there. I was trapped in an unsettling kind of 'backward future' where the (scary) stories I had been told as a young PhD student about academia had become secured as my future. The hours dedicated to my teaching and learning throughout my first seven months as an academic seemed to evaporate on the spot; in spite of their inky presence on my neatly completed evaluation matrix. I left the office hurriedly that day, shoving miscellaneous books and papers into my scrappy black backpack. Outside, in the bright Australian sunshine I shoved in my earphones and used the blaring sound of my rage playlist to drown the disappointment and frustration in the pit of my stomach. Carb on Carb's powerful vocals vibrated through my ears: "resilient, jaded and sore, don't listen to them anymore".

(Heather)

This is an autoethnographic article written by two academics who have recently completed their PhDs and begun full-time academic positions at a Business School in an Australian 
University. Commonly, we would be referred to as 'ECRs' (early career researchers) or 'ECAs' (early career academics); identity categories intended to capture the liminal period from newly minted $\mathrm{PhD}$ to established academic. The increasingly used category ECR (Laudel and Gläser, 2008) has an evolutionist ring to it. An ECR is often conceptualised as a specific identity and career phase, usually extending to 5 years post-doctorate, during which new academics develop 'skills and experiences that will help foster their transition to independence' (Laudel and Gläser, 2008: 388). Scholars have emphasised that ECRs are involved in heightened identity work as they attempt to establish academic identities in relation to life circumstances, political commitments, and the pressures of academic life (Bothello and Roulet, 2019; Crozier and Woolnough, 2019; Bristow et al., 2017). Identity work is conceptualized as a coping mechanism through which people form, maintain, or strengthen their sense of self (Alvesson, 2010) and strive to be 'able to exercise creative potential within constraints imposed by social structures' (Coupland et al., 2008: 331). The identity of an ECR is, therefore, an influential way of interrogating how those 'new' to academia learn what it means to be part of the academy (Huopalainen and Satama, 2019; Robinson et al., 2017).

In the broader landscape of management and organization studies (MOS), focusing on newcomers 'powerfully surfaces the nuances that characterize members' worldviews in a given occupation' (Anteby et al., 2016: 198). Newcomers understand their emerging identities through 'the work one needs to accomplish' in order to become an established member of a community (Pratt et al., 2006; Anderson-Gough et al., 2000: 1153). Such 'work' means that identities are simultaneously learned and resisted 'through the disciplinary techniques of rankings, assessments, and monitoring aimed at self-improvement' (Costas and Grey, 2014: 915; Thornborrow and Brown, 2009). The notion of self-improvement implies a temporal dimension to identity, wherein individuals undertake such a project to realize a 
more 'ideal' self in the future (Grey, 1994; Thornborrow and Brown, 2009) or resist such organizational ideals over time (Bristow et al., 2017). These notions of learning and selfimprovement are firmly embedded in the literature on ECR identity. The identity of an ECR is frequently framed in terms of progress or development as scholars learn to be part of the academy (Laudel and Gläser, 2008), develop skills to navigate the tensions they encounter (Bristow et al., 2017; Williamson and Cable, 2003) and learn to negotiate their (emerging) academic identity with other identities such as a mother (Huopalainen and Satama, 2019; Riad, 2007). Accordingly, focusing on ECRs offers an inroad into understanding how newcomers may challenge and/or reinforce organisational or professional norms.

Importantly, the identity of an ECR has been conceptualised with a particularly salient 'timebounded' or temporal dimension. Time has long been acknowledged by sociologists to shape our identities; both in terms of codified forms of time - such as schedules, calendars, clocks, timetables (Zerubavel, 1981) - and more implicit cultural notions of time both personal (Adam, 2013) and ideological (Halberstam, 2005). Scholars of identity work in MOS have explored the ways in which 'past' and 'future' ideas about the self are influential in constructing identities (Costas and Grey, 2014; Guo, 2018; Ravasi et al., 2019). Brown (2006: 741) for instance, argues that for identity narratives, temporality 'is an extremely flexible narrative resource that can be squeezed and expanded, made to seem episodic or linear, and imposed upon to create beginnings and endings which, in turn, define eras of supposed progress and regress, order and chaos'. Temporality, then, is both shaped by the context and interpreted and understood by individuals as they negotiate their identities. In academia, notions of time are shaped by codified forms of time such as teaching terms, deadlines for grants, review cycles and so on, and ideologically informed cultural notions of time such as the rapid pace of publication which can be tied to neoliberalist ideals of 'progress', 'efficiency' and 'development' (Vostal, 2016; Walker, 2009). These experiences 
of time are deeply felt. ECR identities, then, are shaped by the expected timeframe of ECRs (5 years post-doctorate), the rhythm of academic life more broadly, and the concepts of progress and development which often inform how ECRs learn about academic identity.

Although the temporal aspects of ECR identity may seem neutral, they are in fact socially constructed and therefore imbued with power; usually at the expense of those who do not meet expectations of what constitutes progress according to the normative rhythms of career development (Thwaites and Pressland, 2017). Indeed, traditional notions of a career imply linear development towards an improved future state or identity (Costas and Grey, 2014). The experiences of many academics, however, do not neatly coalesce with this time-bounded identity of an ECR or career. Academics have richly documented the persistent fragility and vulnerability that permeates academia (Knights and Clarke, 2014; Bell and King, 2010; Tienari, 2019), demonstrating that what is learnt as an ECR is not necessarily progress toward some ideal future academic identity. Additionally, academic careers are frequently forestalled by numerous systemic barriers such as racism (Gabriel and Tate, 2017), sexism (Crimmins, 2019), or heterosexism (Rumens, 2016); again precluding 'progress' toward an established academic identity.

As new academics we too have felt ourselves out of step, out of place, and out of ECR time. We feel, by turns, too feminist, too queer, too old, or too brown for the dominant conceptualisation of ECR time and identity. In this article, we 'lay ourselves bare' in the tradition of autoethnography (Tienari, 2019), to explore our experiences of ECR identity and temporality in academia over our first year as full-time academics; one of us on a permanent contract, the other on a short-term contract. We draw on queer theory, and in particular the notion of 'queer time' (McCallum and Tuhkanen, 2011), to explore our embodied experiences as ECRs and reconceptualise how new academics learn to be part of the academy 
not in terms of progress, development, and reproduction, but in terms of being out of step, out of place, and, possibly, productive of alternatives. Ultimately, we reflect on how the friction we experienced from being out of step, out of place, and out time, opened up opportunities for us to learn how to become academics differently. From here, our paper is organised into 'moments': the time we spent reflecting on different bodies of literature and on our experiences as ECRs. First, we turn to the literature on identity and becoming to set the scene.

\section{Moments in identity and becoming}

Critical literature on the identity of newcomers at work, has often taken a 'becoming' approach to identity work, exploring the ways that people continually (re)construct, maintain, and reflect on their sense of self, particularly in times of transition (Hay and SamraFredericks, 2016; Parker, 2004; Pritchard, 2010; Scanlon, 2011). Importantly, the concept of becoming usually implies a series of novice-to-expert transitions by which 'new members are inducted into established occupational communities' (Anteby et al., 2016: 190). For instance, Becker et al. (1961) seminal study of medical residents Boys in White documented the socialization processes of becoming doctors and ultimately how the residents came to see themselves as physicians. The becoming lens enables a particular focus on the 'ideological dilemmas that face new entrants to a workplace' (Coupland, 2001: 1103) that may also be expressed as self-doubt, cynicism and distancing from professional ideology (Collinson, 2003; Costas and Fleming, 2009; Ahuja et al., 2019). It is unsurprising, then, that the literature on ECRs has particularly drawn on the becoming lens (Crozier and Woolnough, 2019; Bristow et al., 2017; Bristow et al., 2019; Robinson et al., 2017; Huopalainen and Satama, 2019) as a powerful way of understanding the experiences of newcomers as they learn (or do not learn) to belong to academia. 
Processes of becoming have been largely conceptualized as enabling junior members to establish a workplace identity whether provisional (Ibarra, 1999), transitional (Pratt et al., 2006) or ideal (Lund, 2012). Ibarra (1999: 765) for instance, suggests that, for new members, workplace identity is initially 'provisional' because becoming is a developmental process through which individuals craft a sense of professional self as they 'strive to improve the fit between themselves and their work environment'. These provisional identities are seen as temporary solutions that individuals deploy to bridge the gap between their self-concepts and their yet to be elaborated professional identity (Pratt et al., 2006). For example, Pratt et al. (2006) argue that junior doctors shaped their identities as they learnt more about the work that they were actually doing. Radiology residents who were less confident about the fit between their work and professional identity reverted back to their previously learned student identities, whereas surgical residents who were more confident about their future identity as 'surgeon' added to or 'patched' their identities with alternative conceptualizations. Although becoming is viewed as ongoing (Beech et al., 2016) and laden with identity conflicts (Ibarra and Barbulescu, 2010) and emotional struggles (Ahuja et al., 2019) there remains an underlying assumption that 'new' will become 'expert' over time as part of progress and development toward a more established identity.

The theorization of becoming we therefore suggest, has focused on the processes of 'newcomer-to-expert' yet under-examined the salient temporal and time-bounded aspects of newcomer identities. Becoming has been predominantly framed as progressive learning process; a reflection on 'who I was', 'who I am', and 'who I might become' (e.g. Bolander et al., 2019; Costas and Grey, 2014; Guo, 2018). This conceptualization is underpinned by chronological, or 'bildungsroman', notions of learning about identities as progress and development, even if ideas of the past and future can be repurposed as identities shift and change (Brown, 2006). The incompleteness and complexity of becoming, however, means 
that chronology is only one way of understanding how temporality shapes identity. Here, we turn to queer theory and queer configurations of identity that offers an alternative conceptualisation of becoming.

\section{Moments in queer time}

Queer theory isn't exactly a theory at all. Rather, queer theory is an 'endlessly mutating token of non-assimilation' (Edelman, 1994: 114); a 'continuing 'war of movement' within the present' (Parker, 2002: 159). Queer theory, then, is possibly better characterised as an ongoing disruption and challenge to normativity and categorisation particularly in relation to gender and sexuality. Accordingly, 'queer' is a kind of politics, interconnected, but not reducible to gender and sexual identities, rather than a descriptive demographic category. In MOS, queer theory has primarily been mobilised to explore how LGBT+ identities are shaped through gender norms and heteronormativity (see for instance, King, 2016; Rumens, 2012). There has been a 'slow uptake' of queer theory in organisation studies (Pullen et al., 2016) and its potential to disrupt normativity and categorisation beyond gender and sexuality remains unrealised (Rumens et al., 2018). Nevertheless, there are growing examples of queer theory mobilised as a politics of disruption, to question concepts such as occupational segregation (McDonald, 2016), areas of interest such as Human Resource Management (Rumens, 2017), and the ways that MOS scholar conduct (McDonald, 2013; McDonald, 2017; de Souza et al., 2016) and write about their research (O’Shea, 2019b; Steyaert, 2015; Weatherall, 2019).

Queer theorists have, however, often resisted the 'mainstreaming' of queer ideas; arguing that mainstream use of queer undermines the radical, disruptive, and critical impetus of queer theory (Halperin, 2003). Accordingly, one of the (almost unavoidable) complications when using queer theory is to continue to question, disrupt, and challenge normative ways of 
thinking while being 'straightened' through the norms of scholarly work and publication (Parker, 2002). The tension is something that we have chosen to embrace in our use of queer theory; not quelling the voice which questions whether our use of queer theory is deradicalised while simultaneously using queer theory to disrupt thinking about identity and learning. We come back to this point in 'moments out of ECR time'.

The concept of identity has been at the core of the development of queer theory. In fact, one of the most powerful outcomes of queer theory has been a 'specifically lesbian and gay reworking of the post-structuralist figuring of identity as a constellation of multiple and unstable positions' (Jagose, 1996: 3). Key to a queer post-structuralist reimagining of identity is the ways in which identity is not a stable, prefigured essence, but a becoming which is performative and thereby politically and socially productive of multiple possibilities (Butler, 1999). As McCallum and Tuhkanen (2011: 10) point out, however, the 'becoming' in queer theory is 'figured not so much as a narrative of self-development, a bildungsroman, but embraced as a constant challenge to the limits, norms, and constraints on intelligibility that hem and define a subject'. There are two important, interconnected elements here of a queer configuration of becoming: the rejection of notions of 'progress' and 'development' in understanding the self, and a focus on identities that refuse to be subsumed into the normative narrative. In other words, where 'becoming' has traditionally been configured as an incomplete but progressive learning toward a 'fit' between a sense of self and a context, a queer becoming is the perpetual 'unfitting' of a sense of self and a context, or in other words, ongoing, discontinuous moments of resistance to intelligibility. A queer understanding of identities, then, also impels a queering of the way scholars understand time and temporality in how we learn about our identity. 
Time is organised through 'patterns of associating social events and activities with rigid sequential structures, fixed durations, standard temporal locations, and uniform rates of recurrence... these often constitute binding normative prescriptions' (Zerubavel, 1981: xiixiii). There is a 'right time' to do things and a 'right' length of time to spend on certain activities. For instance, there are socially normative lengths of time to get a promotion, to find a partner, to have children, to be in the workplace, to be at home, to exercise, to have sex, to sleep, to eat. In reference to our focus on ECR time, there is prolific documentation of how long one is supposed to be an ECR (5 years) and how to 'balance' (i.e. distribute time correctly in relation to) specific activities such as teaching, research, and non-work time (Bristow et al., 2019) in order to achieve promotion, professional recognition, and a secure academic position.

The naturalisation of progress or development in relation to particular activities, however, can operate to marginalise or exclude those for whom this 'natural trajectory' does not unfold sequentially or for those whose identities were forged through other configurations of time (Freeman, 2010; O'Shea, 2019b). As O’Shea (2019b) explores, for example, the traditional narrative of 'transition' for non-binary folk from one gender identity to another does not resonate with their experience of the perpetual becoming. As O'Shea (2019b: 42) points out, 'I have instead always been becoming trans'. Our socialised experiences of time thus shape our identities as we learn the temporal patterns related to our sense of self and how our identities do and, perhaps more importantly, do not fit within these rhythms.

Queer identities are those that 'stick out of time rather than... [those which] endure, change, and experience their lives in a flow of time' (O'Shea, 2019b: 274). Queer scholars have, in particular, explored how normative conceptualisations of time are shaped by the institutions of (heteronormative and biological) family, reproduction, and capitalism in ways that 
marginalise queer identities (Halberstam, 2005; Freeman, 2010). Influentially, Edelman (2004) argued that heterosexual constructions of family, reproduction, and capitalism produce a societal fixation on 'reproductive futurism', defined as continual reproduction in search of the fantasy of progress, growth, and survival. As Dale (2014: 120) argues, productive and reproductive labour are intimately intertwined since, 'the household, far from being external to politics and the economy, is central to the flexible adaptation and reproduction of capitalist relations'. This is not only a gendered relation, but also a sexualised relation, where heterosexual cis-men are associated with the workplace and replicating productive relations and heterosexual cis-women are associated with home and replicating reproductive relations. Reproductive futurism is therefore about both the friction of queer identities with interdependent norms of (family) reproduction and (capitalist) production. Alternatively, queer identities which were forged through 'a life unscripted by the conventions of family, inheritance, and child rearing' (Halberstam, 2005: 2) are positioned in opposition to natural 'progress' and 'development' of family and career.

Queer time, then, is a way of exploring the temporal dimensions of identity and how "straight time' of progress, development, and reproduction [is pitted] against a 'queer time' that is out of step, out of place, and, at best, productive rather than reproductive' (Oswin, 2012: 1625). The effect is that queer identities have long been positioned as 'backwards' and as a 'drag on civilisation' Love (2009: 7). Yet, queer people have continually repurposed normative ideas of time, celebrated and 'embraced backwardness in many forms' (Love, 2009: 7). For example, the term 'camp' has a welcoming backwardness, that is, a 'tender concern for outmoded elements of popular culture and... [a] refusal to let go of childhood pleasures and traumas' (Love, 2009: 7). In this and many other ways queer people have found ways to live, to be organized, and to experience time in ways that are indeterminate, unfixed, imprecise, and refuse to engage in literal or symbolic reproductive futurism. 
Becoming, accordingly, can alternatively be characterised by non-linear movement which is sometimes painful and sometimes emancipatory (and sometimes both at once) but always refuses to be subsumed into the dominant narrative (Freeman, 2010). The refusal to be subsumed is part of a queer politics, where queer identities 'endlessly mutate'; characterised by their 'unfitting' with normativity (Edelman, 2004). The non-linear movement and refusal to be subsumed is a 'chafing'; a sore point produced by repeated friction between moving objects (Edelman, 2004: 6). This ‘friction' of queer identities and queer time against normalisation encapsulates the 'incomplete, partial, or otherwise failed transformations into the social field' while emphasising that, 'perhaps that is a state to enjoy, rather than to just mourn' (Freeman, 2010: xiii). The simultaneous pain, refusal, and emancipatory potential of friction against normative temporal rhythms as the opportunity to be otherwise is a particular focus of queer time.

Queer time, then, is not about a particular future or past, but a refusal to abandon the past (Love, 2009; Freeman, 2010), be denied a future (Sedgwick, 1990; Sedgwick, 1994), or be bounded by the present (O'Shea, 2018; O'Shea, 2019b). The power of queer time for exploring how ECRs learn (not) to belong to the academy lies in its potential to create ongoing disruption to naturalised rhythms of time and identity that marginalise or exclude other ways of being, moving, and learning. Importantly, queer time has a dual focus on the painful friction of unfitting, embodied by ECRs who struggle with or resist 'ideal' academic demands, and 'the moment of opportunity' (McCallum and Tuhkanen, 2011: 9) as ECRs may to learn to be otherwise through their unfitting. Friction emphasises the endlessly mutating, painful, refusal to be subsumed by dominant narratives and opportunity underscores the 'asynchronous, discontinuous pieces of time' (Freeman, 2010: xii) in which this friction offers opportunities to be otherwise. 
To summarize, queer theory proposes a reframing of becoming not as chronological progress or development but as a movement which is continually in friction with the normative limits of identity. Temporality, therefore, remains central to a queer conceptualisation of becoming, but a temporality of friction and discontinuous opportunity rather than a linear path toward self-improvement. Queer time is a concept which encapsulates this simultaneous 'friction' and 'opportunity'. It is the willingness to embrace the tensions between the pain of unintelligibility and the simultaneous power of non-normative lives which opens up political opportunities for other imaginings of time and identity (Love, 2009). Queer time, we argue, offers us a way to understand how learning and identity can be thought of as discontinuous moments of friction which produce the opportunity to be otherwise, rather than as a narrative of progress and development over a linear period of time. We now turn to these discontinuous moments in our experiences; we turn to autoethnography.

\section{Moments in collaborative autoethnography}

'We are taught to master methods that exclude the capriciousness of immediate experience. When we do, we find ourselves in a world devoid of spirituality, emotion, and poetry [...]' (Bochner, 1997: 422).

Autoethnography is about connecting the author's experiences to the social and cultural.

Taking the 'auto' as a focus on the self and 'ethnography' as the study and writing of culture, autoethnography emerges as a reflexive method of inquiry for researchers to explore how their identities and experiences are shaped by social phenomena (Boylorn and Orbe, 2013). The value of autoethnography lies in its reflexive capacity for the researcher to more deeply understand the social world by unpacking their position within it (Behar, 1996).

Autoethnographic accounts tend to be emotive, personal, reflexive, and take the examination of identity as the core focus. Autoethnographies range from primarily 'emotive' accounts which focus on refracting experience from particular positions through storytelling and more 
'analytical' accounts which blend storytelling elements with explicit academic analysis (Wall, 2016). Our approach is more analytical, pairing short vignettes of our experience with analysis of their features in relation to queer time and ECR identity. Although autoethnography has proved a valuable method for those in a more privileged position (Huopalainen and Satama, 2019; Tienari, 2019), it is frequently utilised by those who are marginalised in a particular society; such as those who are queer (O'Shea, 2018; Eguchi, 2015). As autoethnography allows the researcher to examine their own identities it thereby offers communities who have often lacked control over how they are portrayed to shape the narrative and present previously silenced political or ethical positions (O'Shea, 2019b).

While autoethnography is always a relational pursuit (Turner, 2013), as it involves writing the self and others into social and cultural contexts, collaborative autoethnographies may help breakthrough the dichotomy between self and other by introducing the multi-subjectivity of collaboration (Chang et al., 2012). Collaborative autoethnography can, however, sound oxymoronic as it seems to contradict autoethnography's focus on the self. The 'collaborative' dimension refers to the processes of engaging in dialogue between individual researchers' exploration of the self. The aim is to explore how multiple authors' experiences of the self, contribute to understanding a social phenomenon in order to surface different but interconnected insights about the social and cultural context.

For our collaborative autoethnography, we followed the process outlined by Chang et al. (2012). In the first phase collaborative autoethnography, each we each wrote down our 'personal memory data' about the specific topic. Our interest in ECR identity, learning, and queer time, focused our personal memory data around these themes. We specifically thought and wrote about moments in our first year as ECRs in which we felt out of place, out of step, out of time, and like we were in friction with the norms of academia. In the first phase of our 
collaborative autoethnography, each of us contributed our unique experiences related to our transition into the academy. In the second phase, we came together and discussed our 'moments'. In our first discussion we read our moments to each other (which was a liberating yet exposing experience) and asked questions about the experience to draw out further emotive or analytic insights. We then edited our moments and added new ones inspired by our discussions. Together we agreed that we would not edit each other's 'moments' but would assist each other through our engagement and interest in the details of the experience, the feelings they evoked, and what we learnt about becoming academics differently.

In the third and final phase, we gathered all our personal data material and theorized it together. We decided to focus on particular themes that would give insight into the learning of identity and the temporal experiences of ECRs as there were too many themes and the moments were too detailed to include in the length of a journal article. We came together with our edited moments and started looking for similarities and differences as well as discussing the perceived cultural and social features of our experiences. It became clear that there were several common themes in our moments, including gender, class, and familial status, as well as several divergences in themes including sexuality, mental health, ethnicity, and age. We both had different experiences of these themes, although agreed that these other identities shaped how we learn about our ECR identity. We repeated this third phase three times, to extend and develop the analysis of our moments, drawing inspiration from one another and adding clarifications where necessary, including during the review process. In the moments that follow, we discuss how we learnt about our ECR identities and theorize these moments in relation to queer time; connecting our personal experiences to our academic community.

\section{Moments in ECR time}


In the spirit of queer time, and in the tradition of queer autoethnographies, we have opted to organise our autoethnography against a chronological grain (O’Shea, 2019b; McDonald,

2013). We have taken 'moments' of our time as ECRs and arranged them according to experiences of being 'out of step', 'out of place', and 'out of time'. These moments are vignettes; experiences we recognised 'as time shapes life differently' (Steyaert, 2015: 175), in our first year as ECRs. The moments presented are discontinuous, in that they do not necessarily relate to a developing or progressing understanding of our identities as ECRs but nevertheless, highlight moments of learning to become academics. We focus on these moments because we understand them as simultaneously 'moments of friction', where something (painful) was learnt about ECR identity and academic norms, and 'moments of opportunity' for us to harbour the possibility of learning to become ECRs differently. In organising our autoethnography into discontinuous moments, we aim to disrupt the normative temporal dimensions of ECR identity in a bid to explore how learning can be alternatively understood through queer time.

\section{Out of step}

After discussing the importance of thinking ahead for promotion and developing a publication plan across our five years as an ECR, in a 'planning your research career' workshop, we are asked to map our own plan for the next three years. "If 'you had a magic wand' and all your dreams could come true", the facilitator says, "what would your next three years look like?" I don't think we are meant to take that too literally; I would change a lot of things about the world in the next three years and none of those things involve promotion. I stare at the sheet of paper in front of me with its three headings: teaching, service, research. I've still not written anything by the time we are asked to share with our group. They tell me of their plans to publish two A or $A^{*}$ [highly ranked journals] papers in the next three years then apply for a promotion. My goal feels stupid.

I want to write about beautiful, radiant things. I want to share these things with others. I don't know who I want to be when I grow up. I tell this to my group. 
There are clear temporal expectations for ECRs in Heather's moment: a researcher who has a regular publication rhythm and progresses their career within a given time frame. The 'new' neo-liberal context of academia has significantly impacted how those who have recently entered the academy understand their identities compared with those in previous decades, particularly in relation to repeated, rapid publishing in certain outlets (Huopalainen and Satama, 2019; Katila, 2019). New researchers are expected to enact a kind of 'project of the self' in which they seek continuous improvement in order to increase their (market) value (Liu, 2019). Many of these expectations are codified. The 'two publications' articulated by Heather's group members indicates the normative rate of recurrence of publication, the five and three-year time frames offered by the facilitator are evidence of both a fixed duration of ECR identity and the progress ideal, conceptualised as achieving promotion through selfimprovement. This rigid sequential expectation of ECRs toward 'progress' in their career and the codification of ECR time shape the friction Heather experiences as she learns about how her ECR identity does not belong.

The codified temporal rhythms are grounded in an ideological valuing of time which positions progress, efficiency and self-improvement as ideals in the academy (Vostal, 2016; Walker, 2009). Beyond publication, however, are a variety of other expectations which ECRs must 'balance', as is experienced by both Neha and Heather:

I'm trying to set goals for my work plan, trying to visualize what 'making it' looks like in academia. Is it the $A^{*}$ pub club? Student feedback survey ratings in the top percentile? Media piece? Research income? Sustaining a work life balance? Struggle to stay afloat?

The fluidity of my becoming reminds me - in liquid modernity we must improve infinitely, with no final state (Bauman, 2000). I dream of exiting this situation as I scribble - 'No guarantees!' 
I sign up to run a university-based two-week teaching program for underprivileged children over summer. Someone calls me 'brave', which, as a friend of mine says, often feels code for 'I wouldn't do it and I kind of think you made the wrong choice'. Someone else says to me: 'you've really thrown yourself into the university here. Most other people on short term contracts would keep their heads down and churn out the publications'. I'm told by someone else that 'it's good work, really good work, but won't help your career'.

I sign up to run it again the following year. And by then, I might not have my academic job anymore...

(Heather)

Although publication is often seen as a 'gold standard' for ECRs, and thus ECR identity often emphasises the ' $R$ ', there are increased demands for excellence in a wide range of skills from teaching, to public engagement, to procuring grants (Pitt and Mewburn, 2016). The 'selfhelp' academic guides, such as Hay's How to be an academic superhero (Hay, 2017), underscore this perceived need to excel in all dimensions of academic work and to 'balance' these dimensions correctly (Bristow et al., 2017). Moreover, academics are expected to 'balance' these dimensions regardless of the socio-political context, in line the individualistic bent of neoliberal ideology (Thwaites and Pressland, 2017). There is documentation on how 'excellence' has become central to academic identities, and particularly tied to 'survival' as a new academic (Robinson et al., 2017). Halberstam (2005: 4) argues that as a society 'we create longevity as the most desirable future, applaud the pursuit of long life (under any circumstances) and pathologize modes of living that show little or no concern for longevity'. A similar logic could be applied to academic lives: there is, arguably, a celebration of those who carefully craft long-term publication plans, look ahead to promotion, prepare and plan for grants years in advance. However, the search for a future in which this ideal is realised is a search for a fantasy (Edelman, 2004). A fixation on the progress and development toward an ideal future (identity) leads to a futile search for a completion of 'becoming' and an exclusion of those who refuse (or are unable) to be intelligible within that search. Accordingly, even those who do 'excel' in all those dimensions can face the very real threat 
of precarious employment (or no employment) and may have their future as an academic put at risk because of their marginal identities or the inequalities inherent in the neoliberal context which unevenly impact ECRs (Liu, 2019; Thwaites and Pressland, 2017).

It is these norms which both Heather and Neha come up against in their moments of being 'out of step' with the temporal expectations of ECRs. Heather feels 'backward' (Love, 2009) and 'too feminist', and is aware of her inability to become intelligible in a way that will fit within the fixed ECR timeframe. Neha feels overwhelmed by the expectations and unable to identify a clear path to becoming an 'ideal' academic. Being out of step with ECR time is a painful and precarious experience. Yet, although the temporal dimensions of ECR progress and development are restrictive, Neha and Heather opt to embrace the indeterminacy of becoming academics. Heather embraces her backward position in that moment and Neha's 'no guarantees' signals a humorous acceptance of the aphantasia of a stable academic self. Neha and Heather engage in a refusal to hem their identities as academics through normative, prescribed temporal rhythms. The refusal to be subsumed into the future orientation allows, Heather and Neha to 'continue to endure a vulnerable life as it repeats' rather than to ceaselessly attempt to progress or develop an ideal identity (O’Shea, 2019b: 47). Identities that are lived out in ways that are not designed for longevity push against the currents of the progress and development narrative (Edelman, 2004). A painful position; but one that causes friction with the ideal of progress as an ECR by being 'out of step', embracing indeterminacy and the opening opportunities of learning to become an academic - differently.

\section{Out of place}

I approach a colleague at the end of my first teaching semester. The student feedback surveys have just been released. I've never taught undergraduate business students before. This was meant to be a validation of my progress. Although I'd had years of prior experience of promoting myself regardless of my insecurities, this was new to me. 'You'll never get a great SFS [...] coz you're...brown...woman', she says. 
I dread becoming a (more) vulnerable-woman-academic.

(Neha)

For Neha, this was intended as a validation (Pratt et al., 2006) of her emerging academic identity through a collegial reflection on the first teaching semester of a new year. It was, instead, a painful reminder of being 'too brown' and thus ethnically 'out of place' for the normative career progression. Experiences of the academy are shaped by other intersecting aspects of identity such as race (Gabriel and Tate, 2017), sexuality (Rumens, 2016; Giddings and Pringle, 2011), age (Trethewey, 2001; Harris et al., 1998), and gender (Thwaites and Pressland, 2017). Identities which are 'out of place' in a normative academy often have material effects that impede career advancement and a feeling of belonging in the academic world (Thwaites and Pressland, 2017; Gabriel and Tate, 2017). For instance, the white, western, foundations of business school education have resulted in most research and teaching reflecting white knowledge and practices (Cummings et al., 2017; Molisa, 2010), that has a serious impact on 'career development, propensity to publish, or the opportunities for taking more powerful roles in the institution [for scholars of colour]' (Dar, 2019: 442) . This is the feeling of being out of place that Neha comes up against in her experience of teaching evaluations where she experiences pain that her racial identity may forestall her career progression.

Importantly, these variegated identities shape temporal experiences related to 'past' and 'future'. The erasure of the knowledge of scholars and people of colour is an erasure of a past and thus scholars of colour may find it difficult to craft a liveable academic identity for themselves that is not erased by whiteness (Dar, 2019; Molisa, 2010). Neha's feeling of 'dread' of this past/future speaks to her uneasy experience of these temporal relations expected of ECRs. There is no past to draw on, so it is difficult to imagine a future. Although the friction with a history of whiteness is painful, the 'war of movement' Neha feels can also 
be understood as a moment of opportunity to unsettle academic norms and embody a different academic identity.

The unsettling of traditional notions of 'past' and 'future' is an experience Neha had many times relating to her age. Eager to talk about her new job, Neha calls a friend, hoping she can share some of her feelings of dread and excitement around finishing her $\mathrm{PhD}$ and starting a new career in academia, only to be reminded that she is 'too old' to start a new career:

'You are FUCKING CRAZY!' Her tone is shrill, 'You don't need to do this you know you have a career you've got a PhD now just go back to [..] you don't need this! You'll start at the bottom of the shit heap again!' 'I know' I say tentatively, 'but I want to stay close to my research'.

I'm uncertain, drifting. It doesn't feel like progress.

(Neha)

It's my first week as a new 'academic'. 30 years of working across corporates, running an SME and as a mother of 2 teenagers, I don't feel new. The professor's introductory email says: 'the new Business School hire and I will meet at 3pm tomorrow. Can you let everyone know so that they can meet her if around'. Bah what's in a name? Having cultivated a great deal of acceptance of the struggles 'another day at the office' throws you - I am entirely unprepared for this designation. I am the 'new hire'.

I am disciplined so I know my place. I want to scream, 'seriously? I'm too old for this shit!'

(Neha)

In these moments, for Neha, the past and future do not exist in a straightforward chronology.

Taking on the 'new' role as ECR does not feel like progress. Instead, the professor's introduction is a non-linear movement that sequesters and renders invisible her long career experience. In other words, the considerable contributions Neha can bring - teaching ability, mentoring, reflective ability, leadership and team building - are, by virtue of her age and ethnicity, out of place with the normative notions of progress and development. As women of colour in academia have richly documented, gender and 'browness' is frequently 
marginalised in the academy and such racism operates as a barrier to full participation or recogntiion (Gabriel and Tate, 2017). In this moment, Neha feels simultaneously new and old, at the beginning of her career and toward the end. Rather than marking a moment of realisation, a clear shift from past to future, Neha sticks out of the times which hem her identity. Yet, as scholars of queer time point out, the pain and erasure of the past and the possible denial of futures are not situations to mourn but to embrace (Ahmed, 2011; Edelman, 2004; Freeman, 2010; Love, 2009), as Heather experiences in a moment of being 'out of place':

I watch others work around me or connect with others through their phones, computers, books, and papers on the desks before them. I feel outside of time; like I've been sunk into suffocating sludge, every process slowed to the point where life progresses around me and I... I am stuck. Words I might have once said, ideas I might once have had, are in that flow of time around me. But I cannot lift my arm and bring them close to me. I cannot see myself existing beyond this moment; a foreshortened future.

I'm depressed. I can add that clarity in retrospect.

It is only something I can write of now. Then, I could not write. I think of Kyung-Sook Shin:

"Is that how it goes with writing? That as long as you are writing, no time is ever completely in the past? Is this the fate that befalls writers - to flow backward, in present tense, into a time of pain, like salmon migrating upstream, swimming against the current back to where it started, struggling through waterfalls that break and tear its fins?"

I sat in front of my computer and tried not to cry then. Now, I tear at my fins.

(Heather)

In the moments of both Neha and Heather, there is an expected 'future-orientation' of ECRs that they come up against. They experience their pasts as either sites of erasure or of pain, and pasts that do not 'fit' within this future-orientation of progress and development. In different ways, related to their intersecting identities, Heather and Neha struggle to imagine a liveable future that flows from the past. Heather characterises this as 'swimming upstream', 
against the current of normative time. Neha feels disciplined by her designation as a 'new hire' that erases her past experience while learning that it may also be a 'necessary price to pay' for realizing her desire of becoming an academic at her age (Thornborrow and Brown, 2009: 356). Yet, Heather and Neha also feel that being out of place is not transitory but rather a continuous state of becoming as non-traditional ECRs. A future as an academic is often unknowable; the past is often erased. As Ahmed (2011: 160) argues, however, 'to affirm an order [of time] might be to define and regulate what is thinkable in advance of thought'. There is a productive potential in intentionally refusing a scripted future that flows from a definable past (Edelman, 2004). Such a refusal instigates friction with the future orientation of ECR identity and the consistent pressure to plan for a desirable future. In learning to become differently, Heather and Neha engage in reimagining a painful past and embracing the 'vague glimpses' (O'Shea, 2019b) of an uncertain future or, 'a future of perhaps' (Ahmed, 2011: 178), of academic identity rather than a clearly imagined progression of identity from past self to future self.

\section{Out of time}

'Mum, I don't understand what you are doing, but if it makes you happy then I'm happy too!' I hold him close. I want to tell my son, 'some days I'm just drowning can't quite get there'.

(Neha)

The conflict between the reproductive time of mothers and the pressures of academic time have been well documented as barriers to career progression for women. While researchers have remarked that the flexibility of academic work (or time) allows for multiple spheres to exist simultaneously (Huopalainen and Satama, 2019; Katila, 2019; Riad, 2007), those spheres are often set in competition for priority. Motherhood, for instance, has been explored as a competing aspect of identity that causes 'friction' for some women in the academy; 
although such identities can be negotiated to (imperfectly) coexist (Huopalainen and Satama, 2019). Researchers have noted that women frequently carry the 'double burden' of paid work as well as the primary responsibility of domestic labour and childcare (van Amsterdam, 2015; Huopalainen and Satama, 2019). The pressure to 'get things done' in academia pits motherhood as a care giving action against career aspirations generating considerable anxieties and self-doubt about the 'right time' for motherhood and career advancement (Faulkner, 2012; Lund, 2012). For Neha, the metaphor of 'drowning' evokes fears of immobility and isolation as she struggles to combine motherhood and professional ambitions (Huopalainen and Satama, 2019). Family commitments may limit academic mothers capacity to work long hours, disrupting ECR time by marginalizing motherhood in the 'gendered pathways to success' (Harris et al., 1998: 143). Mothers may feel 'out of time' to get the work done, and accordingly, unable to align their reproductive time with their academic time.

Despite a commitment to her academic career, Neha is reminded by this male professor that she may never meet the [promotion] criteria of a 'serious academic':

He mutters, 'the overachiever type' under his breath. But I hear him. Was that a nervous twitch? "Yes!' I want to shout out. I'm working hard to prove to myself and others that I'm a serious academic.

I'm making a concerted effort to rid myself of the professor's words. I am silenced.

The feeling of being out of time that Neha comes up against is fuelled by her desire for perfection, both; as a 'good mother' and being perceived as a 'serious academic'. As van Amsterdam (2015: 271) explains, 'a successful academic' woman, is seen as someone who devotes 'all her time and energy to the university', making it untenable to simultaneously be a 'good mother'. Indeed, this desire for perfection may become a mechanism of control excluding many mothers from the workplace and reinforcing a sense of isolation (Shaw and Cassell, 2007). Queer time, however, is positioned in opposition to reproductive rhythms. 
Edelman (2004) emphasises that queer lives stick out of these reproductive rhythms literally, through existing outside normative conceptions of family and childrearing, and symbolically, through being unwilling to reproduce the social order defined by reproduction. All lives are shaped by these normative reproductive rhythms, as Neha experiences, but, as Edelman suggests, there are lives that stick out of these rhythms. For those who understand their identities according to other conceptualisations of time, there is the possibility of producing, 'alternative temporalities by allowing their participants to believe that their futures can be imagined according to logics that lie outside of those paradigmatic markers of life experience - namely birth, marriage, reproduction, and death' (Halberstam, 2005: 2), as Heather's moment illustrates:

'The Balanced Researcher' workshop facilitator holds up a clear plastic tube filled with different coloured stress balls. They remind me of planets in a solar system some child has on display. In turn he points to each one, giving it a label: family; teaching; exercise; research; admin. 'These balls', he says, 'represent the different parts of our lives. Here they are in balance, each given its own space. But!' He exclaims. 'If we add this shiny new thing' - represented by a golden stress ball - 'that seems so exciting, what happens to the other balls?' He pauses as if for dramatic effect. He shoves the shiny ball into the tube and holds it up as evidence. We laugh, a little awkwardly I feel. 'And in my experience, he says, which ball loses out? Family'. I look around the room at the other women, several of whom are the primary care givers for their children. Is he trying to invoke mum guilt? I tune out his instruction. I have no children. I will never have children.

My life is made up of less definable moving parts: mental illness; familial and nonfamilial platonic relationships; activism; academia; music; dance; domestic labour; care work; reading fiction; writing fiction. I don't fit. I spill.

Heather feels herself stick out of the reproductive rhythms offered by the facilitator in her workshop. She both acknowledges her non-assimilation with normative notions of family and childbearing and her non-assimilation with the consequent reproductive organisation of academic time. A sort of parallel to the 'biological clock' of childbearing, academia has its own 'reproductive clock' for ECRs. As Katila et al. (2019: 13) argue, if new academics do 
not 'reproduce' within the correct time frame, their 'failure to learn and perform may result in the loss of recognition as an academic'. Yet, Heather's understanding of her queer identity in friction with the reproductive rhythms of cis-heterosexual motherhood also affords her the opportunity to imagine her academic identity outside of the reproductive rhythms of academia. Her identity as an ECR, then, is understood in other logics of time that do not imagine the possibility of categorising or balancing various aspects of her life. She spills out of time, rather than attempting to live within the flow of time.

Heather's experience can be understood as productive rather than reproductive. As a contrast to Neha's experiences of motherhood and academia, Heather illustrates that other conceptualisations of temporality are possible. This is not to say, of course, that Heather is not shaped by the same reproductive rhythms that Neha comes up against. On the contrary, Heather moves in and out of these rhythms, referring to some of them in her alternative conceptualisation of academic identity while 'tuning out' of others. As Freeman (2010: 172) argues of queer time, reproductive rhythms 'generate the very unpredictabilities on which new social forms feed'. Reproductive and productive rhythms, then, can also be disrupted in a number of ways from uncoupled academics (Høg Utoft, 2020) to enacting the gendered norms of parenthood differently. Interrupting reproductive rhythms, literally and symbolically, can be productive of alternative ways of imagining how identities can be forged in academia, moving in and out of norms in different tempos. What queer theory offers us here is the conceptual resources to imagine 'unscripted lives' (Halberstam, 2005: 2) particularly when positioned outside norms of (heterosexual, nuclear) family because of legal and socio-political relations. Heather suggests that these resultant identities can be unfixed, imprecise, and unable to be neatly balanced like stress balls in a plastic tube but can 'spill' beyond normative boundaries. 


\section{Moments out of ECR time}

What have we learnt about our identities as ECRs? Our aim in drawing on queer theory was to disrupt our thinking on becoming academics. There is a strong narrative around ECR identity as a transitional identity, as a bridge from newcomer to expert. It was a narrative that we had already come up against during our first year as academics. We felt ourselves out of step and out of place on this bridge. Additionally, we had already unsettled this narrative by taking the persistent fragility of academic identity as our starting point (Knights and Clarke, 2014; Tienari, 2019). We seemed to diverge from the bridge before we had found another path. Still, our engagement with queer theory was a way of understanding how this perpetual becoming could be an opportunity for alternatives even while acknowledging and examining the influence of power and temporality (Costas and Grey, 2014). Queer time offered us that inroad. Our moments in ECR time were riddled with with ambivalences of self and laden with complex emotions such as anxiety, fear, and self-doubt (Beech et al., 2012; Knights and Clarke, 2014; Beech et al., 2016). Yet, as scholars of queer time have emphasised, a lack of clear categories, foundations, or direction is not necessarily a state to mourn but may be a state of opportunity.

Critical scholars of ECR identities have usefully explored how tensions in first years in the academy shape the ways ECRs learn about themselves as scholars (Bristow et al., 2019; Huopalainen and Satama, 2019; Robinson et al., 2017; Katila et al., 2019). Yet, such conceptualisations continue to be underpinned by notions of learning as progress and development. In this view, ECRs learn their identities as a kind of 'bildungsroman' drawing on their past selves and their ideals of the future to understand their identity. A bildungsroman conceptualisation of temporality underpins many studies of identity, particularly the studies of newcomers (Coupland, 2001; Pratt et al., 2006; Ibarra, 1999), as well as studies of learning more broadly (Hay and Samra-Fredericks, 2016; Sturdy et al., 
2006; Bolander et al., 2019; Hay, 2014). For us, however, the bildungsroman conceptualisation of newcomer identity and learning was only one way of understanding how time and temporality shaped ECRs learning about their academic identity. Additionally, it is also only one way of understanding how newcomers may cause friction with the norms of academia and disrupt normative identity trajectories.

In contributing to wider discussions on 'learning as becoming' in which learning 'involves the construction of identities' (Hay and Samra-Fredericks, 2016; Sturdy et al., 2006: 852; Lave and Wenger, 1991: 53; Bolander et al., 2019), we have suggested that newcomers to academia may learn their identities differently. Through queer time we reconceptualised becoming as discontinuous moments of friction and opportunity. These moments were tied to non-chronological understandings of time and temporality. In the telling of our moments, we embraced indeterminacy as we felt ourselves out of step with normative notions of ECR time. We felt friction with absent pasts and vague futures when we felt our intersecting identities were out of place in the academy. We moved in and out of the social norms available to us in academia in order to construct alternative identities that spilt beyond categorical and reproductive boundaries. Conceptualisations of queer time enabled us to highlight how these moments of pain, as we felt the ebbs and flows of powerful norms that shape identity, were simultaneously moments of opportunity (Love, 2009; Halberstam, 2005; McCallum and Tuhkanen, 2011) in which we could learn to become academics differently.

We still deeply feel the friction and opportunity of coming up against the norms of academia and disrupting normative identity trajectories as we have throughout this paper. Here, in the 'closing' (opening?) moments we question whether undertaking this project has helped us to become academics 'differently'. We did, after all, want to publish this article in Management Learning, which is recognised as part of the 'A-pub-club' and would be beneficial to our '5- 
year-career-plan' (if either of us actually crafted such a thing). Even though this came from a desire to share our experiences with other like-minded scholars and connect to the 'quirky' (Bell and Bridgman, 2018) conversations in this journal - does our bringing of the political project of queer theory and time cause friction and/or are we undermining the impetus of queer theory by knowingly allowing ourselves to 'be (somewhat) straightened' by the norms of academic publication?

Our (uncertain) answer is that, as other scholars of queer identity theory in MOS have highlighted, queer identities can be cyclical, they can have no future, they can lead nowhere (O’Shea, 2019a; O’Shea, 2019b; O’Shea, 2018; Steyaert, 2015; McDonald, 2013). The moments we dedicated to writing, thinking, and feeling the ideas in this paper were never intended to contribute to a progress or development or even a 'self-improvement' toward an ideal academic identity. Our moments in this journal may go nowhere, be cyclical, or have no future. Instead, we seek 'a future of perhaps' (Ahmed, 2011), an uneasy relation to a future we cannot see and a past that causes us pain and erasure. Our exploration of 'perhaps' does not suggest, however, that rejecting notions of progress and development equates to assuming nothing is learnt. On the contrary, queer theory helped us to explore how we learnt about our academic identities and how even these painful moments of experience could be an opportunity to produce alternatives identities.

So, what from our moments in queer time can we embrace? What might have the potential to help us learn to become academics differently? From queer time we have learnt that our 'moments of friction' with the normative trajectory of academic identity can be what allows us to endure (O’Shea, 2019b) rather than progress toward some already known and established identity. Those norms of development and the rhythms of progress newcomers come up against generate the unpredictability within which we can create the opportunity to 
be otherwise (Freeman, 2010). In our refusal to abandon our painful pasts of our erasure by whiteness or patriarchy or heterosexism or ageism; in our refusal to ceaselessly seek selfimprovement for an ideal future that never arrives; in our refusal to live a scripted life, we can find new constellations of being, moving, and learning. There is pain in sticking out of normative ECR identity and a very real threat of being denied an academic future that may be experienced as a 'learn or die' moment. Nevertheless, it is in the moments of friction, riddled with indeterminacy in which, we suggest, is the opportunity to disturb academic and ECR identity. While such alternatives may be unfixed, imprecise, and often barely visible, we may yet endure. 


\section{References}

Adam B (2013) Time and Social Theory. Hoboken, NJ: John Wiley \& Sons.

Ahmed S (2011) Happy Futures Perhaps. In: Tukhanen M and McCallum E (eds) Queer

Times, Queer Becomings. Albany: State University of New York Press.

Ahuja S, Heizmann H and Clegg S (2019) Emotions and Identity Work: Emotions as

Discursive Resources in the Constitution of Junior Professionals' Identites. Human Relations 72(5): 988-1009.

Alvesson M (2010) Self-doubters, strugglers, storytellers, surfers and others: Images of selfidentities in organization studies. Human Relations 63(2): 193-217.

Anderson-Gough F, Grey C and Robson K (2000) In the Name of the Client: The Service

Ethic in Two Professional Service Firms. Human Relations 53(9): 1151-1174.

Anteby M, Chan C and DiBenigno j (2016) Three Lenses on Occupations and Professions in Organizations: Becoming, Doing, and Relating. The Academy of Management Annals 10(1): 183-244.

Bauman Z (2000) Liquid Modernity. Cambridge: Polity Press.

Becker H, Geer B, EC H, et al. (1961) Boys in White. Chicago: Chicago University Press.

Beech N, Gilmore C, Cochrane E, et al. (2012) Identiy Work as a Response to Tensions: A Re-narration in Opera Rehersals. Scandinavian Journal of Management 28: 39-47.

Beech N, Gilmore C, Hibbert P, et al. (2016) Identity-in-the-Work and Musicians' Struggles: The Production of Self-Questioning Identity Work. Work, Employment \& Society 30(3): 506-522.

Behar R (1996) The Vulnerable Observer: Anthropology Breaks Your Heart. Boston, MA:

Beacon Press.

Bell E and Bridgman T (2018) Expecting the unexpected in Management Learning. Management Learning 49(1): 3-7. 
Bell E and King D (2010) The elephant in the room: Critical Management Studies conferences as a site of body pedagogics. Management Learning 41(4): 429-442.

Bochner AP (1997) It's About Time: Narrative and the Divided Self. Qualitative Inquiry 3(4): 418-438.

Bolander P, Holmberg I and Fellbom E (2019) Learning to Become Manager: The Identity Work of First Time Managers. Management Learning 50(3).

Bothello J and Roulet TJ (2019) The Imposter Syndrome, or the Mis-Representation of Self in Academic Life. Journal of Management Studies 56(4): 854-861.

Boylorn R and Orbe M (2013) Critical Ethnography: Intersecting Cultural Identities in Everyday Life. New York: Routledge.

Bristow A, Robinson S and Ratle O (2017) Being an Early-Career CMS Academic in the Context of Insecurity and 'Excellence': The Dialectics of Resistance and Compliance. Organization Studies 38(9): 1185-1207.

Bristow A, Robinson S and Ratle O (2019) Academic Arrhythmia: Disruption, Dissonance, and Conflict in the Early-Career Rhythms of CMS Academics. Academy of Management Learning \& Education 18(2): 241.

Brown A (2006) A Narrative Approach to Collective Identites. Journal of Management Studies 43(4).

Butler J (1999) Gender Trouble: Feminism and Subversion of Identity. New York: Routledge. Chang H, Ngunjiri FW and Hernandez K-AC (2012) Collaborative autoethnography. Walnut Creek, CA: Left Coast Press.

Collinson D (2003) Identities and Insecurities: Selves at Work. Organization 10(3): 527-547. Costas J and Fleming P (2009) Beyond Dis-identification: A Discursive Approach to SelfAlienation in Contemporary Organizations. Human Relations 62(3): 353-378. 
Costas J and Grey C (2014) The Temporality of Power and the Power of Temporality: Imaginary Future Selves in Professional Service Firms. Organization Studies 35(6): 909-937.

Coupland C (2001) Accounting for Change: A Discourse Analysis of Graduate Trainees Talk of Adjustment. Journal of Management Studies 38(8): 1103-1119.

Coupland C, Brown A, Daniels K, et al. (2008) Saying it with Feeling: Analysing Speakable Emotions. Human Relations 61(3): 327-353.

Crimmins G (2019) Strategies for resisting sexism in the academy: Higher education, gender and intersectionality. Cham, Switzerland: Palgrave Macmillan.

Crozier SE and Woolnough H (2019) Is age just a number? Credibility and identity of younger academics in UK business schools. Management Learning Online First: 1-19.

Cummings S, Bridgman T and Hassard J (2017) A New History of Management. Cambridge, UK: Cambridge University Press.

Dale K (2014) Family Household and Reproduction. In: Parker M, Cheney G, Fourneir V, et al. (eds) The Routledge Companion to Alternative Organizing. London, UK:

Routledge, pp.120-134.

Dar S (2019) The Masque of Blackness: Or, Performing Assimilation in the White Academe. Organization 26(3): 432-446.

de Souza M, Brewis J and Rumens N (2016) Gender, the Body and Organization Studies:

Queer(y)ing Empirical Research. Gender, Work \& Organization 23(6): 600-613.

Edelman L (1994) Homographesis: Essays in Gay Literary and Cultural Theory. New York: Routledge.

Edelman L (2004) No Future: Queer Theory and Death Drive. Duke University Press. 
Eguchi S (2015) Queer Intercultural Relationality: An Autoethnography of Asian-Black (Dis)Connections in White Gay America. Journal of International and Intercultural Communication 8(1): 27-43.

Faulkner S (2012) That baby will cost you: An Intended Ambivalent Pregnancy. Qualitative Inquiry 18(4): 333-340.

Freeman E (2010) Time Binds: Queer Temporalities, Queer Histories. Durham: Duke University Press.

Gabriel D and Tate SA (2017) Inside the ivory tower: Narratives of women of colour surviving and thriving in British academia. London, UK: UCL Institute of Education Press.

Giddings L and Pringle J (2011) Heteronormativity at Work: Stories From Two Lesbian Academics. Women's Studies Journal 25(2): 91-100.

Grey C (1994) Career as a Project of the Self and Labour Process Discipline. Sociology 28(479-497).

Guo K (2018) The Odyssey of Becoming: Professional Identity and Insecurity in the Canadian Accounting Field. Critical Perspectives on Accounting 56: 20-45. Halberstam J (2005) In a Queer Time and Place: Transgender Bodies, Subcultural Lives. New York: New York University Press.

Halperin D (2003) The Normalization of Queer Theory. Journal of Homosexuality 45(2-4): 339-343.

Harris P, Thiele B and Currie J (1998) Success, Gender and Academic Voices: Consuming Passion or Selling the Soul? Gender and Education 10(2): 133-148.

Hay A (2014) 'I Don't Know What I'm Doing!': Surfacing Struggles of Managerial Identity Work. Management Learning 45(5): 509-524. 
Hay A and Samra-Fredericks D (2016) Desperately Seeking Fixedness: Practitioners' Accounts of 'becoming' Doctoral Researchers. Management Learning 47(4): 407423.

Hay I (2017) How to be an Academic Superhero: Establishing and Sustaining a Successful Career in Social Sciences, Arts and Humanities. Cheltenham, England: Edward Elgar Publishing.

Høg Utoft E (2020) 'All the single ladies' as the ideal academic in times of Covid-19?

Gender, Work \& Organization Early View.

Huopalainen A and Satama S (2019) Mothers and Researchers in the Making: Negotiating 'New' Motherhood within the 'new' Academia. Human Relations 72(1): 98-121. Ibarra H (1999) Provisional Selves: Experimenting with Image and identity in Professional Adaptation. Administrative Science Quarterly 44: 764-791.

Ibarra H and Barbulescu R (2010) Identity as Narrative: Prevalence, Effectiveness, and Consequences of Narrative Identity work in Macro Work Role Transitions. Academy of Management review 35(1): 135-154.

Jagose A (1996) Queer Theory: An Introduction. New York: NYU Press.

Katila S (2019) The Mothers in Me. Management Learning 50(1): 129-140.

Katila S, Laamanen M, Liahonen M, et al. (2019) Becoming Academics: Embracing and Resisting Changing Practice. Qualitative Research in Organizations and Management.

King A (2016) Queer Categories: Queer(y)ing the Identification 'Older Lesbian, Gay and/or Bisexual (LGB) Adults' and Its Implications for Organizational Research, Policy and Practice Gender, Work \& Organization 23(1): 7-18.

Knights D and Clarke C (2014) It's a Bittersweet Symphony, this Life: Fragile Academic Selves and Insecure Identities at Work. Organization Studies 35(3): 335-357. 
Laudel G and Gläser J (2008) From apprentice to colleague: The metamorphosis of Early Career Researchers. Higher Education 55(3): 387-406.

Lave J and Wenger E (1991) Situated Learning: Legitimate Peripheral Participation.

Cambridge: Cambridge University Press.

Liu H (2019) An embarrassment of riches: The seduction of postfeminism in the academy.

Organization 26(1): 20-37.

Love H (2009) Feeling Backward: Loss and the Politics of Queer History. Harvard: Harvard University Press.

Lund R (2012) Publishing to Become an 'ideal academic': An Institutional Ethnography and a Feminist Critique. Scandinavian Journal of Management 28(3): 218-228.

McCallum EL and Tuhkanen M (2011) Queer times, Queer becomings. Albany, NY: State University of New York Press.

McDonald J (2013) Coming out in the field: A queer reflexive account of shifting researcher identity. Management Learning 44(2): 127-143.

McDonald J (2016) Occupational Segregation Research: Queering the Conversation. Gender, Work \& Organization 23(1): 19-35.

McDonald J (2017) Queering Methodologies and Organizational Research: Disrupting, Critiquing, and Exploring. Qualitative Research in Organizations and Management 12(2): 130-148.

Molisa P (2010) White Business Education. Critical Perspectives on Accounting 21(6): 525528.

O’Shea S (2018) This Girl's Life: An Autoethnography. Organization 25(1): 3-20.

O’Shea S (2019a) Cutting My Dick Off. Culture and Organization 25(4): 272-283.

O’Shea S (2019b) My Dysphoria Blues: Or why I Cannot Write an Autoethnography. Management Learning 50(1): 38-49. 
Oswin N (2012) The queer time of creative urbanism: family, futurity, and global city Singapore.(Report). Environment \& Planning A 44(7): 1624-1640.

Parker M (2002) Queering Management and Organizations. Gender, Work \& Organization 9(2): 146-166.

Parker M (2004) Becoming Manager: Or, The Warewolf Looks Anxious in the Mirror, Checking for Facial Hair. Management Learning 35(1): 45-59.

Pitt R and Mewburn I (2016) Academic Superheroes? A Critical Analysis of Academic Job Descriptions. Journal of Higher Education Policy and Management 38(1): 88-101.

Pratt M, Rockmann K and Kaufmann J (2006) Constructing Professional Identity: The Role of Work and Identity Learning Cycles in the Customization of Identity Among Medical Residents. Academy of Management Journal 49(2): 235-262.

Pritchard K (2010) Becoming an HR Strategic Partner: Tales of Transition. Human Resource Management Journal 20(2): 175-186.

Pullen A, Thanem T, Tyler M, et al. (2016) Sexual Politics, Organizational Practices: Interrogating Queer Theory, Work and Organization. Gender, Work \& Organization 23(1): 1-6.

Ravasi D, Rindova V and Stigliani I (2019) The Stuff of Legend: History, Memory, and the Temporality of Organizational Identity. Academy of Management Journal 52(5): 1523-1555.

Riad S (2007) Under the Desk: On Becoming a Mother in the Workplace. Culture and Organization 13(3): 205-222.

Robinson S, Ratle O and Bristow A (2017) Labour pains: Starting a career within the neoliberal university. ephemera 17(3): 481-508.

Rumens N (2012) Queering Cross-Sex Friendships: An Analysis of Gay and Bisexual Men's Workplace Friendships with Heterosexual Women. Human Relations 65(8): 955-978. 
Rumens N (2016) On the violence of heteronormativity within business schools. In: Köllen T (ed) Sexual orientation and transgender issues in organizations: Global perspectives on LGBT workforce diversity. Cham, Switzerland: Springer International Publishing, pp.389-404.

Rumens N (2017) Queering Lesbian, Gay, Bisexual and Transgender identites in Human Resource Deveoplment and Management Education Contexts. Management Learning 48(2): $227-242$.

Rumens N, de Souza M and Brewis J (2018) Queering Queer Theory in Management and Organization Studies: Notes Toward Queering Heterosexuality. Organization Studies 40(4): 593-612.

Scanlon L (2011) 'Becoming' a Professional. In: Scanlan L (ed) 'Becoming' a Professional: An Interdisciplinary Analysis of Professional Learning. Dordrecht: Spinger.

Sedgwick E (1990) Epistemology of the Closet. Berkeley, CA: University of California Press. Sedgwick E (1994) Tendencies. Milton Park, UK: Taylor \& Francis Ltd.

Shaw S and Cassell C (2007) “That's Not How I See it”: Female and Male Perspectives on the Academic Role. Women in Management Review 22(6): 497-515.

Steyaert C (2015) Three Women. A kiss. A Life. On the Queer Writing of Time in Organization. Gender, Work \& Organization 22(2): 163-178.

Sturdy A, Brocklehurst M, Winstanley D, et al. (2006) Management as a (Self) Confidence Trick: Management Ideas, Education and Identity Work. Organization 13(6): 841860.

Thornborrow T and Brown A (2009) 'Being Regimented': Aspiration, Discipline and Identity Work in the British Parachute Regiment. Organization studies 30(4): 355-376. Thwaites R and Pressland A (2017) Being an Early Career Feminist Academic: Global Perspectives, Experiences and Challenges. London, UK: Palgrave Macmillan. 
Tienari J (2019) One flew over the duck pond: Autoethnography, academic identity, and language. Management Learning 50(5): 576-590.

Trethewey A (2001) Reproducing and Resisting the Master Narrative of Decline.

Management Communication Quarterly 15(2): 183-226.

Turner L (2013) The Evocative Autoethnographic 'I': The Relational Ethics of Writing about One-self In: Short N, Turner L and Grant A (eds) Contemporay British Autoethnography. Rotterdam: Sense, pp.213-229.

van Amsterdam N (2015) Othering the 'leaky body'. An Autoethnographic Story About Expressing Breast Milk in the Workplace. Culture and Organization 21(3): 269-287. Vostal F (2016) The Pulse of Modern Academia. In: Vostal F (ed) Accelerating Academia: The Changing Structure of Academic Time. Basingstoke: Palgrave Macmillan, pp.110.

Walker J (2009) Time as the Fourth Dimension in the Globalization of Higher Education. The Journal of Higher Education 80(5): 483-509.

Wall S (2016) Toward a moderate autoethnography. International Journal of Qualitative Methods 15(1): 1609406916674966.

Weatherall R (2019) Writing a Doctoral Thesis Differently. Management Learning 50(1): $100-113$.

Williamson IO and Cable DM (2003) Predicting early career research productivity: the case of management faculty. Journal of Organizational Behavior 24(1): 25-44.

Zerubavel E (1981) Hidden Rhythms: Schedules and Calendars in Social Life. Chicago, IL: University of Chicago Press. 